Harmoni Sosial: Jurnal Pendidikan IPS

Volume 3, No 1, Maret 2016 (95-104)

Online: http://journal.uny.ac.id/index.php/hsjpi

\title{
HUBUNGAN EQ, PENGETAHUAN KEWIRAUSAHAAN, DAN HASRAT \\ MARGINAL MENABUNG, DENGAN MOTIVASI BERWIRAUSAHA MAHASISWA \\ PENDIDIKAN EKONOMI
}

\author{
Tri Handayani, Suyanto \\ Program Studi PIPS, Konsentrasi Pendidikan Ekonomi, Universitas Negeri Yogyakarta \\ Trimugle@yahoo.com, suyan@ymail.com
}

\begin{abstract}
Abstrak
Penelitian ini bertujuan untuk mendeskripsikan korelasi kecerdasan emosional, pengetahuan kewirausahaan, dan hasrat marginal menabung dengan motivasi berwirausaha mahasiswa Pendidikan Ekonomi FKIP Universitas Negeri Jambi. Penelitian ini merupakan penelitian korelasional. dengan populasi mahasiswa Pendidikan Ekonomi FKIP Universitas Negeri Jambi dan sampel penelitian ini adalah mahsiswa angkatan 2012 sebanyak 79 orang yang dipilih dengan teknik nonprobability purpose sampling. Teknik pengumpulan data yang digunakan yaitu angket untuk kecerdasan emosional, hasrat marginal menabung dan motivasi berwirausaha dan tes untuk pengetahuan kewirausahaan. Teknik analisis yang digunakan adalah correlasi product moment dengan taraf signiikansi 0,05 . Hasil penelitian menunjukkan bahwa: (1) Terdapat hubungan positif dan signifikan antara kecerdasan emosional dan motivasi berwirausaha dengan determinasi korelasi 0,456 , pada taraf signifikan 0,05 (2) Terdapat hubungan positif dan signifikan antara pengetahuan kewirausahaan dan motivasi berwirausaha dengan determinasi korelasi 0.459, pada taraf signifikan 0,05. (3) Terdapat hubungan positif dan signifikan antara hasrat marginal menabung dan motivasi berwirausaha dengan determinasi korelasi 0,517, pada taraf signifikan 0,05 (4) Terdapat hubungan positif dan signifikan secara bersamaan antara kecerdasan emosional, pengetahuan kewirausahaan, dan hasrat marginal menabung dengan motivasi berwirausaha dengan determinasi korelasi 0,625 , pada taraf signifikan 0,05
\end{abstract}

Kata kunci: kecerdasan emosional, pengetahuan kewirausahaan, hasrat marginal menabung, motivasi berwirausaha.

\section{KORELATION EQ, ENTREPRENEUR KNOWLEDGE, AND MARGINAL PROPENSITY TO SAVE WITH ENTREPRENEUR MOTIVATION OF STUDENT ECONOMIC EDUCATION}

Tri Handayani, Suyanto

Program Studi PIPS, Konsentrasi Pendidikan Ekonomi, Universitas Negeri Yogyakarta

Tri_mugle@yahoo.com, suyan@ymail.com

\begin{abstract}
This research aims to describe the relationship between emotional inteligency, entrepreneur knowledge, marginal propensity to save, and entrepreneurship motivation of students majoring in Economic Education Science, in Teacher Education Faculty, Jambi University. This is correlation research. The population of this research was students majoring Economic Education Science of Teacher Education Faculty, Jambi
\end{abstract}


University and the sampel was 79 students from 2012 intake using nonprobability purpose sampling tehnique. The data were collected using questionnaire of emotional inteligency, marginal propensity to save, entrepreneur motivation and tes of entrepreneur knowledge. The data were analyzed using correlation product moment with level of significant 0.05 . The research finding reveals that: (1) There is a positive and significant relationship between emotional inteligency and students entrepreneurship motivation with a correlation coefficient 0.456, in level of significant 0.05; (2) There is significant relationship between entrepreneurship knowledge and student entrepreneurship motivation with a correlation coeffivient 0.459 , in level of significant 0.05 ; (3) There is significant relationship between marginal propensity to save and entrepreneurship motivation with a correlation coefficient 0.517, in level of significant 0.05; (4) There is significant relationship between emotional inteligency, entrepreneurship knowledge, and marginal propensity to save with students entrepreneurship motivation with a correlation coefficient 0.625 in level of significant 0.0 .5

Keywords: emotional inteligency, entrepreneur knowledge, marginal propensity to save, entrepreneurship motivation.

\section{Pendahuluan}

Jumlah penduduk di Provinsi Jambi berdasarkan data BPS tahun 2011 sebanyak 3.169.814 jiwa. Jumlah pengangguran Terbuka di Provinsi Jambi pada tahun 2013 (Februari) mencapai 45,900 jiwa. Pengangguran ini kebanyakan dari kaum intelek yang menyandang gelar pendidikan tinggi. Menurut Sudradjat (2005, pp.6-8) teerdapat lima penyebab pengangguran yaitu; warisan sifat feudal dari penjajah berupa rasa gengsi dengan pekerjaan swasta; tidak adanya motivasi untuk bekerja karena malas; lapangan kerja yang tersedia memerlukan skill khusus; pertumbuhan ekonomi disertai dengan laju perkembangan penduduk yang tinggi menyebabkan pertumbuhan ekonomi semakin berat yang berakibat tingkat investasi yang dilakukan pemerintah maupun swasta juga lamban; dan karena menemui jalan buntu dalam mencari pekerjaan yang menyebabkan timbulnya sikap tidak percaya diri dan apatis. Jika hal ini di biarkan terus menerus akan berdampak kepada pertumbuhan perekonomian. Pengangguran ini biasanya disebabkan kurangnya lapangan pekerjaan bagi para lulusan sarjana-sarjana muda tersebut padahal jika mereka memiliki bekal pengetahuan, motivasi dan modal untuk berwirausaha mungkin hanya sedikit pengangguran ditengah-tengah banyaknya jumlah sarjana-sarjana muda tiap tahunnya.

Motivasi merupakan dorongan yang muncul dari dalam diri seseorang untuk melakukan suatu kegiatan. Menurut Eman Suherman (2008, p. 15) motivasi merupakan dorongan yang muncul karena adanya kebutuhan atau adanya rangsanan dari luar diri yng bersangkutan. Sedangkan menurut Djamara (2008, p. 148) motivasi merupakan suatu perubahan eneri di dalam pribadi seseorang yang ditandai dengan timbulnya afektif (perasaan) dan reaksi untuk mencapai tujuan. Motivasi sangat berhubungan dengan suatu tujuan, semakin besar tujuan yang ingin dicapai maka semakin kuat pula motivasinya. Ketika seseorang memiliki suatu keinginan yang kuat untuk dicapai maka dapat dilihat semakin besar dorongan atau motivasi tersebut unuk mendapatkan apa yang diinginkan.

Seseorang terdorong untuk berwirausaha menurut Saiman (2014, pp.25-26) dikarenakan adanya berbagai imbalan yang kuat yang dikelompokkan menjadi tiga kategori yaitu; laba; kebebasan; dan kepuasan menjalani hidup. Motivasi berwirausaha ini biasanya muncul karena adanya kebutuhan-kebutuhan yang ingin dipenuhi. Kebutuhan-kebutuhan ini menurut McClelland (dalam Suharyati, 2011, pp.72-73) yaitu kebutuhan akan prestasi, kebutuhan akan kekuasaan, kebutuhan untuk berafiliasi atau bersahabat.

Motivasi berwirausaha di kalangan masyarakat khususnya mahasiswa bisa dikatakan masih sangat kurang karena menurut mereka bahwa berkuliah hanya untuk mendapatkan pekerjaan yang baik saat melamar menjadi karyawan atau pegawai. Selain itu kurangnya tingkat kecerdasan emosional, pengetahuan kewirausahaan, dan modal juga sebagai faktor pendukung rendahnya motivasi berwirausaha 
tersebut. Rendahnya motivasi berwirausaha masyarakat khususnya mahasiswa menyebabkan banyaknya angkatan yang siap untuk bekerja hanya menunggu untuk menjadi karyawan / pegawai sehingga ketika lapangan pekerjaan tersebut tidak dapat menampung semuanya dan menciptakan pengangguran

Pola berpikir menjadi orang yang memiliki pendapatan dari upah pekerja atau pegawai sangat melekat ditengah-tengah masyarakat sehingga kebanyakan para sarjana-sarjana baru memilih untuk menunggu pembukaan lapangan pekerjaan dari pemerintah sebagai pegawai negeri (PNS) daripada berwirausaha, yang kuota penerimaannya terbatas dan tidak mampu menampung semua pengangguran. Selain darai pemerintah juga ada dari pihak swasta seperti, bank, perkantoran, industry, bimbel, pusat perbelanjaan dan lain sebagainya. Pada akhirnya seetiap orang haruslah melihat berdasarkan kenyataan yang ada dan mengerjakan sesuatu berdasarkan kenyataan yang pada saat ini dapat dilakukan yaitu dengan berwirausaha.

Berwirausaha adalah suatu kegiatan dalam melakukan kegiatan wirausaha, yaitu kegiatan yang inovatif dan kreatif dalam menciptakan suatu produk dan jasa. Aspek dasar dari wirausahaa ini menurut Hisrich et all $(2008$, p.8) yaitu terdiri dari roses, waktu, dan penghargaan yang ingin dicapai. Kemampuan dalam berwirausahaa ini disebut kewirausahaan. Kewirausahaan menurut Suryana (2003, p.13) sebagai kemampuan kreatif dan inovatif yang dijadikan kiat, dasar, sumber daya, proses dan perjuangan untuk menciptakan nilai tambah barang dan jasa yang dilakukan dengan keberanian untuk menghadapi resiko.

Kewirausahan merupakan mata kuliah pokok Program Studi Pendidikan Ekonomi. Dalam mata kuliah kewirausahaan, mahasiswa mempelajari sifat-sifat wirausahawan, dan cara-cara untuk memulai suatu usaha. Menurut Zimmerer \& Scarborough (2008, p. 11) kewirausahaan memiliki ruang lingkup yang cukup luas dan dinamis sifatnya, memiliki proses dan sesuatu yang bau sebagai hasil kreatifitaas yang disertai dengan resiko tertentu. Adapun ruang lingku kewirausahaan menurut Hendro (2011, p. 38) yaitu ruang lingkup internal dan ruang lingkup eksternal. Ruang lingkup internal ini yaitu kehidupan sehari-hari, keluar dari kesulitan, untuk tetap bertahan hidup dan mengatasi kebatasan. Ruang lingkup eksternal yaitu, dalam dunia usaha menjadi wirausahawan yang sukses, dalam dunia masyarakat menjai contoh yang teladan di lingkungan sekitar, dalam kehidupan bernegara membantu program pemerintah dala mengurangi tingkat engangguran yang ttinggi dan membantu mengatasi kemiskinan, dan menjadi lokomotif kemajuan ekonomi. Kewirausahaan bukanlah pembawaan/ keturunan, kewirausahaan adalah keahlian yang dapat di pelajari. Meskipun telah dipelajari di bangku kuliah tetapi kebanyakan lulusan dari pendidikan ekonomi memilih bekerja sebagai guru bimbingan belajar, les privat, perkantoran, asuransi, perbankan, dan lain sebagainya.

Dalam menentukan jenis pekerjaan yang diinginkan, dijalani dan ditekuni, setiap mahasiswa (orang) memiliki pola berpikir dan tingkat kecerdasan emosional yang berbeda-beda. Dalam mengambil tindakan dan kepuusan tiap orang memiliki cara berpikir atau pola berpikir yang membedakan antara satu dengan lainya. Baharuddin (2014, pp. 48, 55) mendefinisikan kecerdasan sebagai tingkah laku individu berdasarkan kesanggupan untuk melakukan suatu aktivitas berpikir sedangkan emosi adalah suatu pengalaman yang sadar mempengaruhi kegiatan jasmani dan afektif yang meliputi unsur perasaan yang mengikuti keadaan-keadaan fisiologis dan mental yang muncul dan penyesuaian batiniah dan yang mengekspresikan dirinya dalam tingkah laku yang tampak. Emosi secara harfiah dapat disimpulkan sebagai setiap kegiatan atau pergolakan pikiran, perasaan, nafsu dari setiap keadaan mental yang hebat dan emosi ini yang memfokuskan akal dan logika untuk menetapkan suatu tujuan.

Kecerdasan emosi merupakan kesanggupan seseorang dalam menangapi suatu keadaaan dan mengelolah emosi yang muncul mempengaruhi kegiatan jasmani dan afektif yang tampak dengan di ekspresikan. Kecerdasan emosional ini menurut Nasution et all (2007, p.15) adalah kemampuan membina hubungan yang baik dengan orang lain, mudah mengenali emosi pada orang lain serta penuh perhatian, kecerdasan emosi menambahkan jauh lebih banyak sifat-sifat yang menjadikan kita lebih bersifat manusiawi.

Setiap orang memiliki tingkat kecerdasan emosional yang berbeda-beda. Untuk mengukur 
tingkat kecerdasan emosional ini menurut Goleman (1999, p.42) dapat dilihat pada kecakapan pribadi yaitu; pertama, kesadaran diri yaitu memiliki tolak ukurr yang realistis atas kemampuan diri sendiri dan kepercayaan diri yang kuat meliputi kesadaran emosi, penilaian diri secara teliti, percaya diri. Kedua, pengaturan diri yitu daapt mengendalikan emosi, peka terhadap kata hati dan sanggup menunda kenikmatan sebelum tercapainya suatu sasaran dan mammpu pulih kembali dari tekanan emosi yang meliputi kendali diri, sifat dapat dipercaya, kewaspadaan, adaptibilitas, inovasi. ketiga, motivasi yaitu menggunakan hasrat kita yang paling dalam untuk mmenggerakkan dan menuntun kita menuju sasaran, membantu kita mengambil inisiatif dan bertindak sangat efektif dan untuk bertahan menghadapi kegagalan frustasi yang meliputi dorongan prestasi, komitmen, inisiatif, opttimis.

Kecakapan sosial yaitu; pertama, empati adalah kemampuan merasakan dan meahami perasaan orang lain, menumbuhkan hubungan saling percaya dan menyelaraskan diri dengan bermacam-macam orang yang termasuk empati yaitu memahami orang lain, orientasi pelayanan, mengembangkan orang lain, mengatasi keragaman, kesadaran politis. Kedua, keterapilan sosial yaitu mampu membaca situasi dan membawa diri dalam lingkungan dan hubungan sosial secara baik sehingga mampu mempengaruhi dan memimpin, bermusyawarah, menyelesaikan preselisihan dan dapat bekerjasama dalam tim. Yang termasuk keterampilan sosial yaitu pengaruh, komunikasi, kepemimpinan, katalisator perubahan, manajemen konflik, pengikat jaringan, kolaborasi ddan kooperasi, kemampuan tim.

Di dalam ekonomi terdapat istilah yaitu "menunda kepuasan", yaitu menunda suatu hal dengan berbagai pertimbangan yang nantinya dapat memberikan keuntungan, manfaat dan kepuasan yang lebih besar, dan hal ini di pengaruhi oleh banyak faktor, antara lain kecerdasan emosional (EQ) dalam menentukan tindakan. Sayangnya, kebanyakan orang-orang tidak dapat menahan keinginan dan emosi, tidak dapat menunda kepuasannya tersebut sehingga sering cepat/terburu-buru mengambil tindakan dan keputusan dalam melanjutkan kehidupannya (bekerja). Kecerdasan emosional dan pengetahuan kewirausaan merupakan beberapa faktor dalam berwirausaha selain itu juga modal berupa uang tidak kalah pentingnya.

Dikalangan mahasiswa, untuk memiliki modal berwirausaha bukan menjadi suatu permasalahan walaupun mahasiswa pada umumnya belum bekerja tetapi biaya hidupnya berasal dari kiriman berupa transfer paymen (pemberian), dari orang tua, saudara, maupun beasiswa dari Universitas /pemberi dana bisa disisihkan sebagian kecil untuk ditabung sebagai modal berwirausaha. seperti pernyataan Keynes (1936) tabungan digunakan untuk berinvestasi oleh pengusaha (entrepreneur). Tabungan dapat digunakan sebagai strategi dalam pengembangan aset kewirausahaan, tabungan bisa digunakan salah satunya untuk memulai bisnis kecil.

Ada beberapa faktor yang mempengaruhi tingkat tabungan seseorang menurut Sadono Sukirno (2011, pp. 119-200) yaitu; kekayaan yang telah terkumpul seperti kekayaan yang dimliki sebelumnya/ warisan, suku bunga mempengaruhi tinggi rendahnya tingkat menabung seseorang dan rumah tangga akan lebih banyak menabung apabila suku bunga tinggi karena lebih banyak pendapatan dari tabungan yang akan diperoleh, sikap berhemat, keadaan perekonomian mempengaruhi tingkat menabung, distribusi pendapatan yang pendapatannya lebih seimbang tingkat tabungannya relative sedikit karena mereka mempunya kecondongan mengonsumsi yang sedikit dan tersedia setidaknya dana pension yang mencukupi di hari tua atau tidak jika dana pensiunya hanya sedikit dan kurang menunjang di hari tuanya nanti kebanyakan masyarakat meningkatkan tabungannya di masa kerja begitu juga sebaliknya jika dana pensiunannya dapat mencukupi di hari tua. Untuk mengukur nilai Tabungan tersebut dapat dilihat dari hasrat marginal menabung. Hasrat marginal menabung merupakan pertambahan nilai tabungan akibat adanya pertambahan nilai pendapatan. Menurut Suherman Rosyidi (2011, p.167) hasrat marginal menabung merupakan pertambahan tabungan dibagi dengan GNP. Pada kenyataannya, gaya hidup mahasiswa yang kebanyakan mengikuti arus model yang sedang mutahir, menyebabkan tingkat pengeluarannya besar (konsumtif) sedangkan besarnya tabungan mahasiswa tergantung pada banyak uang yang diterima dan pengeluaranya. Adanya penambahan uang yang diterima baik itu dari orang tua, beasiswa ataupun pendapatan penghasilan sendiri dari bekerja 
sambilan mempengaruhi besarnya penambahan nilai konsumsi dan tabungan. Dengan adanya penambahan nilai tabungan diharapkan dapat digunakan sebagai modal untuk berwirausaha, antara lain membuka suatu usaha sendiri sehingga menghasilkan uang (pendapatan).

Berdasarkan uraian latar belakang masalah tersebut penulis menjadi tertarik untuk melakukan penelitian yang berjudul "Hubungan Kecerdasarn Emosional, Pengetahuan Kewirausahaan, dan Hasrat Marginal Menabung dengan Motivasi Berwirausaha Mahasiswa Universitas Jambi.

\section{Metode Penelitian}

Penelitian ini merupakan jenis penelitian korelasional. Penelitian korelasional adalah penelitian yang digunakn untuk mengukur hubungan antara dua variabel atau lebih tanpa ada upaya untuk mempengaruhi variabel tersebut sehingga tidak terdapat manipulasi variabel.

\section{Tempat dan Waktu Penelitian}

Penelitian ini dilakukan di Program Studi Pendidikan Ekonomi FKIP Universitas Jambi. Adapun waktu penelitian ini dilaksanakan pada tanggal 12, 16, dan 20 maret 2015.

\section{Populasi dan Sampel Penelitian}

Populasi dalam penelitian ini yaitu mahasiswa program Studi Pendidikan Ekonomi FKIP Universitas Jambi. Penarikan sampel dalam penelitian ini menggunakan teknik nonprobability purposev sampling. Adapun kriteria dalam pengambilan sampel ini yaitu mahasiswa yang berstatus aktif, sudah pernah belajar matakuliah kewirausahaan dan memiliki tabungan. Berdasarkan tehnik pengambilan sampel tersebut sehingga didapat 79 mahasiswa pendidikan ekonomi angkatan 2012 sebagai sampel penelitian.

\section{Teknik dan Instrumen Pengumpulan Data}

Teknik pengumpulan data dalam penelitian ini dilakukan dengan dua teknik, yaitu angket, dan tes. Angket digunaka untuk mengetahui kecerdasan emosional, hasrat marginal menabung dan motivasi berwirausaha mahasiswa sedangkan tes untuk mendapatkan data pengetahuan kewirausahaan mahasiswa tersebut.

Instrument pengumpulan data dalam penelitian ini menggunakan angket untuk kecerdasan emosional yang terdiri dari 20 butir pertanyaan, angket terbuka untuk hasrat marginal menabung, angket motivasi berwirausahaa yang terdiri dari 24 butir pernyataan, dan lemar tes untu pengetahuan kewirausahaanyang terdiri dari 45 butir pertanyaan pilihan ganda.

Validitas dan Reliabilitas Instrumen

Dalam penelitian ini validitas angket dan tes diukur dengan menggunakan validitas logis dan validitas empiris. Validitas logis berkaitan dengan validitas isi (content validity) dan validitas konstruk (construct validity) yang akan divalidasi oleh (expertjudgement). Disamping itu, penyusunan instrument juga mendapatkan bimbingan dari pembimbing. Sedangkan validitas empiris dilakukan dengan uji coba instrument hanya pada angket kecerdasan emosional, motivasi berwirausaha dan tes untuk pengetahuan kewirausahaan yang dianalisis menggunakan analisis faktor.

Berdasarkil uji coba instrument yang telah dilakukan, didapat hasil yang pertama, analisis faktor pada variabel kecerdasan emosional yang dianalisis ternyata hasil ekstrasi komputer menjadi 6 faktor. Faktor 1 mampu menjelaskan $27,81 \%$, faktor 2 mampu menjelaskan $13,01 \%$, faktor 3 mampu menjelaskan $10,12 \%$, faktor 4 mampu menjelaskan 7,63\%, faktor 5 mampu menjelaskan $6,80 \%$, faktor 6 mampu menjelaskan $5,83 \%$. Keenam faktor secara keseluruhan mampu menjelaskan $71,2 \%$ variasi.

Melihat dari hasil component matrix,jelas bahwa yang berada pada faktor 1 nomer 12 loading factor sebesar 0,738 , yang berada pada faktor 2 adalah butir angket nomer 13, dengan loading factor 0,734, yang berada pada faktor 3 adalah butir angket nomer 16 dengan loading factor 0,611, yang berada pada faktor 4 adalah butir angket nomer 3 dengan loading factor 0,624, yang berada pada faktor 5 adalah butir angket nomer 18 dengan loading factor 0,632 , dan yang berada pada faktor 6 adalah butir angket nomer 9 dengan loading factor 0,509. Berdasarkan analisis data dari uji validitas angket kecerdasan emosional diperoleh hasil analisis instrument dengan nilai KMO 0,550 > dari 0,500 maka dapat disimpulkan bahwa angket kecerdasan emosional valid.

Kedua, instrument tes pengetahuan kewirausahaan berupa soal tes pilihan ganda yang berjumlah 45 soal dengan system penilaian 0 untuk pilihan jawaban yang salah dan 1 untuk 
pilihan jawaban, tahap uji coba dilakukan pada mahasiswa sebanyk 50 mahasiswa. dari hasil uji coba diperoleh hasil sebagai berikut; dari analisis faktor pada variabel pengetahuan kewirausahaan yang dianalisis ternyata hasil ekstrasi komputer menjadi 16 faktor. Faktor 1 mampu menjelaskan $17,36 \%$, faktor 2 mampu menjelaskan 6,88\%, faktor 3 mampu menjelaskan 5,99\%, faktor 4 mampu menjelaskan 5,59\%, faktor 5 mampu menjelaskan 5,30\%, faktor 6 mampu menjelaskan $4,66 \%$, faktor 7 mampu menjelaskan $4,32 \%$, faktor 8 mampu menjelaskan $4,26 \%$, faktor 9 mampu menjelaskan 3,97\%, faktor 10 mampu menjelaskan 3,54\%, faktor 11 mampumenjelaskan $3,21 \%$, faktor 12 mampu menjelaskan 3,12\%, faktor 13 mampu menjelaskan 2,86\%, faktor 14 mampu menjelaskan $2,74 \%$, faktor 15 mamppu menjelaskan 2,42\% dan faktor ke 16 mampu menjelaskan 2,31\%.. Keenam belas faktor secara keseluruhan mampu menjelaskan $78,53 \%$ variasi.

Melihat dari hasil component matrix yang berada pada faktor 1 nomer 24 loading factor sebesar 0,645 , yang berada pada faktor 2 adalah butir soal nomer 14, dengan loading factor 0,734 , yang berada pada faktor 3 adalah butir soal nomer 26 dengan loading factor 0,513, yang berada pada faktor 4 adalah butir soal nomer 35 dengan loading factor 0,388 , yang berada pada faktor 5 adalah butir soal nomer 3 dengan loading factor 0,524 , yang berada pada faktor 6 adalah butir soal nomer 3 dengan loading factor 0,400 , yang berada pada faktor 7 adalah butir soal nomer 36 dengan loading factor 0,538 , yang berada pada faktor 8 adalah butirr soal nomer 23 dengan loading faktor 0,332, yang berada pada faktor 9 adalah butir soal nomer 41 dengan loading factor 0,397 , yang berada pada faktor 10 adalah butir soal nomer 32 dengan loading faktor 0,511 , yang berada pada faktor 11 adalah butir soal nomer 21 dengan loading faktor 0,364 , yang berada pada faktor 12 adalah butir soal nomer 19 dengan loading loading faktor 0,300, yang berada pada faktor 13 adalah butir soal nomer 15 dengan loading faktor 0,520 , yang berada pada faktor 14 adalah butir soal nomer 32 dengan loading faktor 0,292, yang berada pada faktor 15 adalah butir soal nomer 16 dengan loading faktor 0,317 , dan yang berada pada faktor 16 adalah butir soal nomer 25 dengan loading faktor 0,384.

. Berdasarkan analisis data dari uji validitas tes pengetahuan berwirausaha, diperoleh hasil analisis instrument dengan nilai KMO 0,548 > dari 0,500 maka dapat disimpulkan bahwa tes pengtahuan kewirausahaan valid.

Ketiga, instrument motivasi berwirausaha. Dari hasil uji coba diperoleh data sebagai berikut yaitu dari analisis faktor pada variabel motivasi berwirausaha yang dianalisis ternyata hasil ekstrasi computer menjadi 8 faktor. Faktor 1 mampu menjelaskan 25,65\%, faktor 2 mampu menjelaskan $11,17 \%$, faktor 3 mampu menjelaskan $8,47 \%$, faktor 4 mampu menjelaskan $7,84 \%$, faktor 5 mampu menjelaskan 7,67\%, faktor 6 mampu menjelaskan 5,55\%, faktor 7 mampu menjelaskan $4,86 \%$, faktor, faktor 8 mampu menjelaskan 4,16\%. Kedelapan faktor secara keseluruhan mampu menjelaskan $86,47 \%$ variasi.

Berdasarkan hasil pengolahan data pada tabel component matrix jelas bahwa yang berada pada kelompok 1 adalah butir angket nomer 15 dengan loading factor sebesar 0,659 , yang berada pada kelompok 2 adalah butir angket nomer 16 dengan loading factor sebesar 0,615 , yang berada pada kelompok 3 adalah butir angket nomer 17 dengan loading factor 0,511, yang berada pada kelompok 4 adalah butir angket nomer 4 dengan loading factor sebesar 0,669 , yang berada pada kelompok 5 adalahh butir angket nomer 8 dengan loading factor sebesar 0,567 , yang berada pada kelompok 6 adalah butir angket nomer 9 dengan loading factor sebesar 0,554, yang berada pada kelompok 7 adalah butir angket nomer 19 dengan loading factor sebesar 0,576, yang berada pada kelompok 8 adalah butir angket nomer 21 dengan loading factor sebesar 0,561.

Berdasarkan analisis data uji vaiditas instrument angket motivasi berwirausaha diperoleh hasil analisis bahwa instrument dinyatakan valid apabila nilai KMO lebih besar dari 0,520. Maka dari 24 butir pernyataan angket motivasi berwirausaha diketahui valid semua.

Estimasi realibitas keseluruhan butir angket kecerdasan emosional, motivasi berwirausaha dan butir soal pengetahuan kewirausahaan dapat diperoleh dengan menggunakan koefisien Alpha Cronach. Pada pengukuran reliabilitas instrument angket dilakukan pada satu waktu (one shoot) maka instrument dikatakan reliabel jika nilai Cronbach Alpha lebih besar dari 0,60 (Purbayu \& Ashari 2005, p.251).

Berdasarkan hasiluji coba analisis realibitas instrument didapat data yaitu; pertama, Estimasi 
keseluruhan butir angket kecerdasan emosiona dapat diperoleh dengan menggunakan koefisien alpha cronbach. Adapun hasil uji reliabilitas instrument kecerdasan emosional didapat nilai alpha sebesar 0,823 lebih besar dari 0,60 sehingga instrument kecerdasan emosional dapat dikatakan sudah reliabel. Kedua, Estimasi keseluruhan butir soal pengetahuan kewirausahaan dapat diperoleh dengan menggunakan koefisien alpha cronbach. Adapun hasil uji reliabilitas instrument pengetahuan kewirausahaan nilai alpha sebesar 0,882 >0,60 sehingga instrument pengetahuan kewirausahaan bisa dikatakan reliabel. Ketiga, Berdasarkan hasil konsultasi dengan expert judgment menyatakan bahwa lembar angket terbuka untuk hasrat marginal menabung sudah reliable. Pernyataan-pernyataan yang sudah dinyatakan reliable sudah melalui beberapa perubahan sesuai dengan saran yang diberikan dari ahli, sehingga dinyatakan bahwa instrumen tes tersebut layak digunakan untuk penelitian. Keempat, Estimasi keseluruhan butir angket motivasi berwirausaha dapat diperoleh dengan menggunakan koefisien alpha cronbach. Adapun hasil uji reliabilitas instrument motivasi berwirausaha memiliki nilai alpha sebesar 0,859 lebih besar dari 0,60 sehingga instrument motivasi berwirausaha dapat disimpulkan sudah reliabel.

\section{Teknik Analisis Data}

Uji Prasyarat Analisis

Uji normalitas. Untuk penelitian ini menggunakan uji normalitas Kolmogorof Smirnov (K-S). Uji ini digunakan untuk mengetahui apakah sampel yang digunakan untuk peneitian ini berasal dari popuasi yang berdistribusi normal atau tidak.

Uji linieritas. Dalam penelitian ini menggunakan uji linieritas untuk mengetahui apakah terdapat hubungan secara linier antara variabel bebas dan variabel terikat.

Uji Hipotesi. Untuk menguji hipotesis menggunakan analisis korelasi bivariate dan korelasi berganda produck moment. Analisis korlai digunakan untuk mengetahui hubungan antara satu variabel (variabel bebas) dan variabel lainnya (tak bebas), variabel-variabel tersebut diukur dengan taraf signifikan. analisis korelasi untuk menganalisis hubungann antara variabel bebas, yaitu kecerdasan emosional, pengetahuan kewirausahaan dan hasrat marginal menabung dengan variabel terikat motivasi berwirausaha. Kesimpulan apakan Ho diterima atau ditolak diperolh dengan interprestasi nilai signifikansi pada tabel correlation melalui program SPSS 17.0. kriteria yang digunakan dalam pengambilan kesimpulan adalah jika nilai $\alpha<0,05$ maka Ho ditolak dan Ha diterima. Hipotesis dalam penelitian ini adalah:

$$
\begin{aligned}
& \text { Нa: } p_{1} \neq 0 \\
& \text { Нa: } p_{2} \neq 0 \\
& \text { Нa: } p_{3} \neq 0 \\
& \text { Ha: } p_{1} \neq 0 \text { atau } p_{2} \neq 0 \text { atau } p_{3} \neq 0
\end{aligned}
$$

Hasil Penelitian dan Pembahasan

Dari instrument yang telah disebarkan kepada responden diperoleh data sebagai berikut:

Tabel 1. Kecerasan Emosional Mahasiswa

\begin{tabular}{cccc}
\hline Skor & Frekuensi & Kategori & Persentase \\
\hline$\geq 51$ & 16 & Tinggi & $20,2 \%$ \\
$42-50$ & 51 & Sedang & $64,5 \%$ \\
$\leq 42$ & 12 & Rendah & $15,3 \%$ \\
\hline
\end{tabular}

Rata-rata skor kecerdasan mahasiswa 46,8 dengan kategori Sedang

Berdasarkan tabel 1, dapat diketahui bahwa kecerdasan emosional mahasiswa pendidikan ekonomi FKIP Universitas Jambi dinyatakan tinggi $20,2 \%$ dengan frekuensi 16 mahasiswa, sedang $64,5 \%$ dengan frekuensi 51 mahasiswa, rendah $15,3 \%$ dengan frekuensi 12 mahasiswa dan rata-rata keseluruhan 46,8 termasuk dalam kategori sedang.

Tabel 2. Pengetahuan Kewirausahaan Mahasiswa.

\begin{tabular}{cccc}
\hline Skor & Frekuensi & Kategori & Presentase \\
\hline$\geq 68,05$ & 7 & Tinggi & $7,6 \%$ \\
$32,72-$ & 48 & Sedang & $78,4 \%$ \\
68,04 & & & \\
$\leq 32,72$ & 11 & Rendah & $14 \%$ \\
\hline
\end{tabular}

Rata-rata skor pengetahuan kewirausahaan mahasiswa 50,39 kategori sedang

Berdasarkan tabel 2, dapat diketahui pengetahuan kewirausahaan mahasiswa pendidikan ekonomi FKIP Universitas Jambi dinyatakan tinggi $7,6 \%$ dengan frekuensi 7 
mahasiswa, sedang $78,4 \%$ dengan frekuensi 48 mahasiswa, rendah $14 \%$ dengan frekuensi 11 mahasiswa dan rata-rata keseluruhan 50,39 termasuk dalam kategori sedang.

Tabel 3. Hasrat Marginal Menabung Mahasiswa

\begin{tabular}{cccc}
\hline Skor & Frekuensi & Kategori & Persentase \\
\hline$\geq 0,60$ & 14 & Tinggi & $17,8 \%$ \\
0,09 & 44 & Sedang & $55,6 \%$ \\
$-0,59$ & & & \\
$\leq 0,09$ & 21 & Rendah & $26,6 \%$
\end{tabular}

Rata-rata hasrat marginal menabung mahasiswa 0,34 dengan kategori sedang

Berdasarkan tabel 3, dapat diketahui hasrat marginal menabung mahasiswa pendidikan ekonomi FKIP Universitas Jambi dinyatakan tinggi $17,8 \%$ dengan frekuensi 14 mahasiswa, sedang 55,6\% dengan frekuensi 44 mahasiswa, rendah 26,6\% dengan frekuensi 21 mahasiswa dan rata-rata keseluruhan 0,34 termasuk dalam kategori sedang.

Tabel 4. Motivasi Berwirausaha Mahasiswa

\begin{tabular}{cccc}
\hline Skor & Frekuensi & Kategori & Presentase \\
\hline$\geq 82$ & 8 & Tinggi & $10,3 \%$ \\
$59-81$ & 62 & Sedang & $78,1 \%$ \\
$\leq 59$ & 9 & Rendah & $11,6 \%$ \\
\hline
\end{tabular}

Rata-rata motivasi berwirausaha mahasiswa 70,41 dengan kategori sedang

Berdasarkan tabel 4, dapat diketahui motivasi berwirausaha mahasiswa pendidikan ekonomi FKIP Universitas Jambi dinyatakan tinggi $10,3 \%$ dengan frekuensi 8 mahasiswa, sedang $78,1 \%$ dengan frekuensi 62 mahasiswa, rendah $11,6 \%$ dengan frekuensi 9 mahasiswa dan rata-rata keseluruhan 70,41 termasuk dalam kategori sedang.

Hasil uji normalitas pada penelitian ini didapat bahwa data berdistribusi normal yang dibuktikan pada nilai sig $0,387>\alpha 0,05$ yang berarti data berdistribusi normal. Berdasarkan hasil uji linieritas pada penelitian ini didapat bahwa kecerdasan emosional dan motivasi berwirausaha diperoleh nilai signifikan 0,072 $>0,05$ maka dapat disimpulkan bahwa terdapat hubungan yang linear secara signifikan antara variabel kecerdasan emonional dan motivasi berwirausaha.

Pengetahuan kewirausahaan dan motivasi berwirausaha memiliki nilai signifikan $0,838>$
0,05 maka dapat disimpulkan bahwa terdapat hubungan yang linear secara signifikan antara variabel pengetahuan kewirausahaan dan motivasi berwirausaha. Hasrat marginal menabung dan motivasi berwirausaha memiliki nilai signifikan $0,194>0,05$ maka dapat disimpulkan bahwa terdapat hubungan yang linear secara signifikan antara hasrat marginal menabung dan motivasi berwirausaha.

Hasil analisis data pada kecerdasan emosional dan motivasi berwirausaha dapat dilihat pada tabel berikut:

Tabel 5. Kecerdasan Emosional dan Motivasi Berwirausaha.

\begin{tabular}{ccc}
\hline Korelasi & $\mathrm{N}$ & Pearson Correlation \\
\hline $\mathrm{X}_{1}-\mathrm{Y}$ & 79 & $0,456^{* *}$ \\
\hline
\end{tabular}

Tabel 5 memberikan gambaran bahwa koefisien korelasi kecerdasan emosional $\left(\mathrm{X}_{1}\right)$ dan motivasi berwirausaha $(\mathrm{Y})$ sebesar 0,456 dengan taraf signifikan 0,05 . Hal ini berarti terdapat hubungan yang positif dan signifikan antara kecerdasan emosional dan motivasi berwirausaha dengan demikian, $\mathrm{H}_{\mathrm{a}}$ menyatakan bahwa terdapat hubungan antara kecerdasan emosional dan motivasi berwirausaha mahasiswa dapat diterima.

Hasil analisis data pada pengetahuan kewirausahaan dan motivasi berwirausaha dapat dilihat pada tabel berikut:

Tabel 6. Pengetahuan Kewirausahaan dan Motivasi Berwirausaha.

\begin{tabular}{ccc}
\hline Korelasi & $\mathrm{N}$ & Pearson Correlation \\
\hline $\mathrm{X}_{2}-\mathrm{Y}$ & 79 & $0,459^{* *}$ \\
\hline
\end{tabular}

Tabel 6 memberikan gambaran bahwa koefisien korelasi pengetahuan kewirausahaan $\left(\mathrm{X}_{2}\right)$ dan motivasi berwirausaha $(\mathrm{Y})$ sebesar 0,459 pada taraf signifikan 0,05 . Hal ini berarti terdapat hubungan yang positif dan signifikan antara pengetahuan kewirausahaan dan motivasi berwirausaha dengan demikian, $\mathrm{H}_{\mathrm{a}}$ menyatakan bahwa terdapat hubungan antara pengetahuan kewirausahaan dan motivasi berwirausaha mahasiswa dapat diterima.

Hasil analisis data pada hasrat margial menabung dan motivasi berwirausaha dapat dilihat pada tabel berikut: 
Tabel 7. Hasrat Marginal Menabung dan Motivasi Berwirausaha Mahasiswa

\begin{tabular}{ccc}
\hline Korelasi & $\mathrm{N}$ & Pearson Correlation \\
\hline $\mathrm{X}_{3}-\mathrm{Y}$ & 79 & $0,517^{* *}$ \\
\hline
\end{tabular}

Tabel 7 memberikan gambaran bahwa koefisien korelasi hasrat marginal menabung $\left(\mathrm{X}_{4}\right)$ dan motivasi berwirausaha $(\mathrm{Y})$ sebesar 0,517 pada taraf signifikan 0,05 . Hal ini berarti terdapat hubungan yang positif dan signifikan antara hasrat marginal menabung dan motivasi berwirausaha dengan demikian, $\mathrm{H}_{\mathrm{a}}$ menyatakan bahwa terdapat hubungan antara hasrat marginal menabung dan motivasi berwirausaha mahasiswa dapat diterima.

Hasil analisis data pada kecerdasan emosional, pengetahuan kewirausahaan dan hasrat margial menabung dengan motivasi berwirausaha dapat dilihat pada tabel berikut:

Tabel 8. Kecerdasan Emosional, Pengetahuan

Kewirausahaan, dan Hasrat Marginal Menabung dengan Motivasi Berwirausaha Mahasiswa.

\begin{tabular}{ccc}
\hline Korelasi & $\mathrm{N}$ & Pearson Correlation \\
\hline $\mathrm{X}_{1}, \mathrm{X}_{2}$, & 79 & $0,625^{* *}$ \\
$\mathrm{X}_{3}-\mathrm{Y}$ & & \\
\hline
\end{tabular}

Tabel 8 memberikan gambaran bahwa besarnya hubungan antara kecerdasan emosional, pengetahuan kewirausahaan, indeks prestasi komulatif dan hasrat marginal menabung yang dihitung dengan koefisien korelasi adalah sebesar 0,625 pada taraf signifikan 0,06. Hal ini menunjukkan bahwa terdapat hubungan yang positif dan signifikan antara kecerdasan emosional, pengetahuan kewirausahaan dan hasrat marginal menabung dengan motivasi berwirausaha. $\mathrm{H}_{\mathrm{a}}$ terdapat hubungan yang signifikan antara kecerdasan emosional, pengetahuan kewirausahaan, indeks prestasi komulatif dan hasrat margina menabung terhadap motivasi berwirausaha mahasiswa diterima.

\section{Kesimpulan dan Saran}

Kesimpulan

Berdasarkan analisis dan pembahasan hasil penelitian dapat disimpulkan bahwa: rata-rata kecerdasan emosional mahasiswa secara keseluruhan dilihat dari jumlah nilai rata-rata sebesar 46,8 berada pada kategori sedang. Sumbangan secara parsial kecerdasan emosional mahasiswa dan motivasi berwirausaha memberikan gambaran bahwa koefisien korelasi sebesar 0,456 dengan taraf signifikan 0,05 . Hal ini berarti terdapat hubungan yang signifikan antara kecerdasan emosional $\left(\mathrm{X}_{1}\right)$ dan motivasi berwirausaha $(\mathrm{Y})$. Dengan demikian $\mathrm{H}_{\mathrm{a}}$ yang menyatakan bahwa terdapat hubungan yang signifikan antara kecerdasan emosional terhadap motivasi berwirausaha mahasiswa dapat diterima.

Berdasarkan pengolahan data variabel pengetahuan kewirausahaan dapat dilihat dalam kategori sedang dengan jumlah nilai ratarata keseluruhan sebesar 50,39. Sumbangan secara parsial pengetahuan kewirausahaan dan motivasi berwirausaha memberikan gabaran bahwa koefisien korelasi sebasar 0,459 dengan taraf signifikan 0,05 . Hal ini berarti terdapa hubungan yang signifikan antara hubungan pengetahuan kewirausahaan $\left(\mathrm{X}_{2}\right)$ dan motivasi berwirausaha $(\mathrm{Y})$. Dengan demikian, $\mathrm{H}_{\mathrm{a}}$ yang menyatakan terdapat hubungan yang signifikan antara pengetahuan kewirausahaan dan motivasi berwirausaha dapat diterima.

Berdasarkan pengolahan data variabel hasrat marginal menabung dapat dilihat dalam kategori sedang dengan jumlah skor ratarata keseluruhan sebesar 0,34. Selanjutnya sumbangan secara parsial hubungan hasrat marginal menabung dan motivasi berwirausaha memberikan gambaran bahwa koefisien korelasi sebesar 0,517 dengan taraf signifikan 0,05. Hal ini berarti terdapa hubungan yang signifikan antara hasrat marginal menabung $\left(\mathrm{X}_{3}\right)$ dan motivasi berwirausaha $(\mathrm{Y})$. Dengan demikian, $\mathrm{H}_{\mathrm{a}}$ yang menyatakan terdapat hubungan yang signifikan antara hasrat marginal menabung dan motivasi berwirausaha dapat diterima.

Selanjutnya secara bersaa-sama memberikan gambaran bahwa keeratan hubungan antara kecerdasan emosional, pengetahuan kewirausahaan, indeks prestasi komulatif dan hasrat marginal menabung terhadap motivasi berwirausaha dilihat dari nilai $\mathrm{R}$ sebesar 0,625 dengan signifikan 0,05 . Hal ini menunjukkan bahwa antara kecerdasan emosional, pegetahuan kewirausahaan, indeks prestasi komulatif, dan hasrat marginal menabung secara bersamasama memiliki hubungan terhadap motivasi berwirausaha mahasiswa secara signifikan. dengan demikian $\mathrm{H}_{a}$ yang menyatakan bahwa 
terdapat hubungan yang signifikan antara hasil kecerdasan emosional, pengetahuan kewirausahaan, indeks prestasi komulatif dan hasrat marginal menabung terhadap motivasi berwirausaha dapat diterima.

Saran

Berdasarkan kesimpulan penelitian yang telah diuraikan sebelumnya maka diberikan beberapa saran kepada berbagai pihak yang pertama, Dengan adanya hubungan yang positif dan signifikan atara kecerdasan emosional, pengetahuan kewirausahaan, dan hasrat marginal menabung dengan motivasi berwirausaha mahasiswa, dapat dijadikan sebagai bahan pertimbangan bagi dosen untuk lebih memperhatikan motivasi berwirausaha mahawasiswa yang didukung dengan kecerdasan emosional, pengetahuan kewirausahaan, dan hasrat marginal menabung mahasiswa pada saat menyampaikan materi pembelajaran di ruang perkuliahan. Kedua, untuk mahasiswa yang bersangkutan agar dapat meningkatkan motivasi berwirausahanya sehingga dapat menjadi seorang wirausahawan yang sukses dengan menyadari dan terus meningkatkan kecerdasan emosional, pengetahuan kewirausahaan, dan hasrat marginal menabungnya.

\section{Daftar Pustaka}

Baharuddin. (2014). Pendidikan \& pikologi perkembangan. Yogyakarta: Ar-ruzz Media.

Basrowi. (2011). Kewirausahaan untuk perguruan tinggi. Bogor: Ghalia Indonesia.

Djamarah \& Bahri S. (2008). Psikologi belajar. Jakarta: Rineka Cipta.
Goleman, D. (1999). Working with emotional intelligence. Terjemahan Alex Tri Kantjono Widodo. Jakarta: Gramedia Pustaka Utama.

Hendro. (2011). Dasar-dasar kewirausahaan. Jakarta: Erlangga

Hisrich, R. D., et all. (2008). Entrepreneurship. Singapoer: McGraw-Hill/Irwin.

Keynes, J. M. (1936). The general theory of employment, interest, and money. Cambridge: ISN.

Longenexker, L. G., et all (2001). Small business managemen an entrepreneurial emphasis. Singapore: Thomson Learning.

Nasution, A. H., et all. (2007). Entrepreneurship: Membangun spirit teknopreneurship. Yogyakarta: CV. Andi Ofesen.

Purbayu \& Ashari. (2005). Analisis statistik dengan microsoft excel \& SPSS. Yogyakarta: Andi.

Sadono Sukirno. (2011). Learning more economics 1. Bandung: Grafindo Media Pratama.

Sudradjad. (2005). Kiat mengentaskan Pengangguran Melalui Kewirausaha. Jakarta: Bumi Aksara.

Suharyadi., et all. (2011). Kewirausahaan dan manajemen usaha. Jakarta: Salemba Empat.

Rosyidi S. (2011). Pengantar teori ekonomi. Jakarta: PT. Raja Grafindo Persada.

Suryana. (2013). Wirausaha:Pedoman praktis, kiat dan proses menuju sukses. Jakarta: Salemba Empat. 